Brazilian Journal

of Chemical

\title{
BROMELAIN SEPARATION AND PURIFICATION PROCESSES FROM PINEAPPLE EXTRACT
}

\author{
Danielly C. A. Abreu ${ }^{1}$ and Kátia C. de S. Figueiredo ${ }^{1 *}$ \\ ${ }^{1}$ Universidade Federal de Minas Gerais, Departamento de Engenharia Química, Belo Horizonte, MG, Brasil. \\ ORCID: 0000-0002-6363-6618; E-mail: katia@deq.ufmg.br, ORCID: 0000-0001-7207-1535
}

(Submitted: September 2, 2018 ; Revised: January 3, 2019 ; Accepted: February 26, 2019)

\begin{abstract}
The concern about the effective use of agro-industrial residues from the food industry has increased. Bromelain is an enzyme mainly obtained from the pineapple plant (A. comosus), including its parts normally considered as waste. It is a high value-added product with a wide variety of applications such as in food, cosmetic and pharmaceutical industries. Many approaches have been used to purify this enzyme, but an efficient method to produce highly active and pure bromelain is still highly desirable. The investigated methods include ion exchange chromatography, precipitation, an aqueous two-phase system as well as affinity and filtration membranes. This paper gives an overview about the advantages and limitations of each one. Chronologic results and advances for these separation processes are also shown. The major tendency is the use of combined processes, such as hybrid or integrated ones.

Keywords: Agro-industrial waste; Aqueous two-phase system; Ion exchange chromatography; Membrane; Precipitation.
\end{abstract}

\section{INTRODUCTION}

The concern about the effective use of agroresidues, such as peels, seeds and other materials from the food industry has been increasing (Silvestre et al., 2012). The utilization of such waste is considered an important challenge for all governments that seek for sustainability (Gil and Maupoey, 2018).

Pineapple is the most popular of all tropical fruits and it is an important ingredient in the food industry such as in juice concentrates, jams, jellies, essence, and pickles (Chaurasiya and Hebbar, 2013). However, of this fruit only $25 \%$ of it can be used as a marketable product, while $75 \%$ (leaves, crown, stem and bark) is treated as agricultural waste (Tap et al., 2016). Costa Rica, Brazil and the Philippines are responsible for one third of total pineapple production (Martins et al., 2014; Dossa and Fuchs, 2017).

The progressive increase of pineapple production has led to higher amounts of its waste. The correct disposal of such residue represents a growing problem since it is usually prone to microbial spoilage. The reuse of pineapple waste would be an innovation to deal with this environmental problem (Ketnawa et al., 2012). In fact, pineapple waste has been identified as a potential source of proteases, such as bromelain (Nor et al., 2015).

Bromelain extraction and purification processes have been studied, but there are some restrictions related to the laboratory-scale character of most techniques, which increase the production costs (Coelho et al., 2014).

Purifying bromelain with high activity is also desirable, so effective and economically viable techniques need to be developed (Nadzirah et al., 2013). The goal of this review is to present potential methods to separate and purify bromelain.

\section{Bromelain}

Bromelain is a protein-digesting enzyme categorized as a protease, although it includes nonproteases as well. Protease refers to the group of enzymes which catalyse the hydrolysis of the peptide bonds of proteins (Tap et al., 2016). Its function is similar to papain and ficin (Amid et al., 2011).

\footnotetext{
*Corresponding author: Kátia C. de S. Figueiredo - E-mail: katia@deq.ufmg.br
} 
Among the family of Bromeliaceae, pineapple (Ananas comosus), one of the most popular fruits in the world (Nor et al., 2015), is the best-known source of bromelain (Silvestre et al., 2012). It is naturally extracted from pineapple and can be obtained even from its inedible parts which are normally considered as waste in industry (Nor et al., 2016).

Pineapple is a unique fruit. It contains high concentrations of proteases in the mature stage and this is one of the reasons to use pineapple proteases compared with other natural sources. Bromelain is not present during the premature stage of fruit development, but its level increases fast and remains high until ripening, when its content diminishes slightly (Silvestre et al., 2012).

Bromelain is composed of a complex mixture of proteases and non-proteases, which include stem bromelain $(80 \%)$, fruit bromelain $(10 \%)$, ananain (5\%) and other components (Nadzirah et al., 2013), as shown in Figure 1, and is soluble in water but insoluble in organic solvents (Wan et al., 2016).

Stem bromelain (EC 3.4.22.32), more important from an industrial application point of view as it shows activity over wide range of $\mathrm{pH}$, is the most studied cysteine proteinase within bromelain preparations derived from pineapple stem. On the other hand, fruit bromelain (EC 3.4.22.33) is a glucoprotein proteinase present in pineapple juice (Corso et al., 2012; Bernela et al., 2016). Among the non-protease components, bromelain is composed of phosphatases, glucosidases, peroxidases, cellulases, glycoproteins and carbohydrates (Silvestre et al., 2012).

Stem bromelain is constituted by a single polypeptide chain with 212 amino acids folded into two structural domains stabilized by disulphide bridges and numerous hydrogen bonds (Soares et al., 2012), its molecular mass is $24.5 \mathrm{kDa}$, with a $\mathrm{pI}$ value of 9.55 and diffusion coefficient of $7.77 \times 10^{-7} \mathrm{~cm}^{2} / \mathrm{s}$ (Murachi and Takahashi, 1969). Fruit bromelain presents an isoelectric point at 4.6 (Nadzirah et al., 2013) and molecular mass of $31 \mathrm{kDa}$ (Souza et al., 2005). All commercially available bromelain is derived from the stem (Bala et al., 2013).

Stem bromelain is also very stable, sustaining its activity at temperatures between 40 and $60{ }^{\circ} \mathrm{C}$, in which most enzymes are denatured (Coelho et al.,

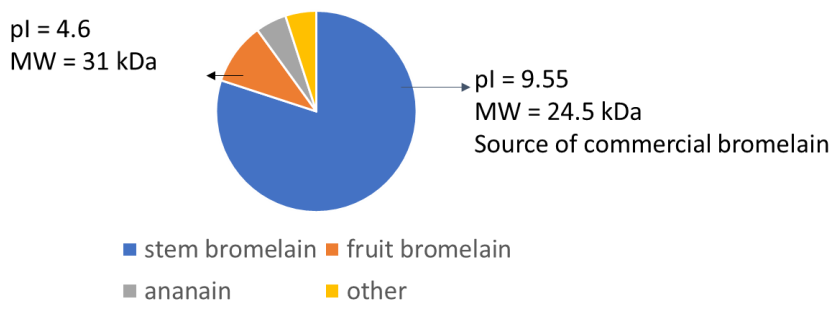

Figure 1. Bromelain distribution and some physicochemical characteristics.
2014). From $\mathrm{pH} 5.5$ to 8.0 , the enzymatic activity of bromelain is kept (Pavan et al., 2012), but this enzyme is usually unstable and sensitive under stress conditions in the presence of elevated temperature, organic solvents and chemicals, which may result in a decrease in its function (Soares et al., 2012). Thus, bromelain activity greatly depends on its biochemical and pharmacological properties.

\section{Applications of bromelain}

Bromelain enzyme has useful functions for the food, pharmaceutical, cosmetics and textile industries (Nor et al., 2016; Wu et al., 2017) and, because of this wide range of applications, commercial bromelain must be highly pure (Ketnawa et al., 2012; Arumugam and Ponnusami, 2013).

In the food industry bromelain has been used for meat tenderization, brewing, baking (Ketnawa et al., 2012; Amid et al, 2011), prevention of browning of apple juice (Bernela et al., 2016), clarification of beer and as a food supplement (Bala et al., 2013). During the process of tenderization, bromelain promote softening of meat by breaking the fibrous material (Coelho et al., 2014). In the baking industry, bromelain improves dough relaxation, allowing it to rise evenly and produce hypoallergenic flour that is suitable for wheatallergic patients (Arshad et al., 2014). Bromelain has been used in this kind of industry because its ideal temperature range of $50-70^{\circ} \mathrm{C}$ is suitable for a food processing application (Amid et al, 2011).

Bromelain has extensive applications as an active ingredient in tooth-whitening dentifrices and skin products to treat acne, wrinkles, and dry skin, reduce post-injection bruising and swelling (Arshad et al., 2014). It is used as an active ingredient to provide mild peeling effects (Bala et al., 2013) and as a cleansing agent (Chaurasiya and Hebbar, 2013).

This enzyme is widely used in the pharmaceutical industry as a drug for treatment of inflammatory ailments, intestinal disorders, blood-coagulation related diseases, improved absorption of antibiotics (Nor et al., 2015), as wound debridement agent, as a fibrinolytic agent (Chaurasiya and Hebbar, 2013), oral treatment for third degree burns (Bernela et al., 2016), therapeutic application for antibodies (Tap et al., 2016) and for mucolytic action (Costa et al., 2014).

It has also been applied for anticancer activity, in the immunization of influenza virus and in the treatment of allergic airway disease (Lopes et al., 2009). The explanation of bromelain anticancer activity is that this enzyme may exert its antitumor effects by inducing cytokine production (Amid et al., 2011).

Another range of therapeutic benefits has been claimed for bromelain, such as reversible inhibition of platelet aggregation, sinusitis, surgical traumas, thrombophlebitis, pyelonephritis angina pectoris 
(Pavan et al., 2012) and relief from bronchitis (Amid et al., 2011).

Due to a lack of side effects and its effectiveness after oral administration, bromelain earned growing acceptance as an herbal drug and may be found as tablets and capsules (Coelho et al., 2014). In fact, bromelain is only poorly absorbed when administered orally, generating plasma levels of less than $10 \mathrm{ng} / \mathrm{mL}$ in humans given $4 \mathrm{~g}$ /day (Hale et al., 2005).

In textile industries, bromelain is incorporated in leather processing (Wu et al., 2017) and it is also used for improving the dyeing qualities of protein fibers, decomposing or partially solubilizing protein fiber from silk and wool (Bala et al., 2013).

Other applications for bromelain are production of protein hydrolysates, hair removal (Ketnawa et al., 2012), as a fiber softener in detergent (Wu et al., 2017) and alcohol production (Tap et al., 2016).

The importance of determining a viable extraction and purification method for this enzyme is increasing with the broad range of its applications (Costa et al., 2014), and the most common processes are presented next.

\section{SEPARATION PROCESS}

The commercial production of bromelain from pineapple consists of several steps such as extraction, purification, drying and packing in the powder form (Nor et al, 2015). The isolation and purification stages require the most expensive materials and operations or are exceedingly laborious (Amid et al., 2011). In fact, considering both economic and technical aspects, the purification step corresponds to $70-90 \%$ of the total production cost (Soares et al., 2012).

It is desirable that the purification is cost-effective, rapid, high-yielding and robust. Moreover, it should allow continuous product recovery, with a high capacity and selectivity for the desired products (Bala et al., 2012). Many approaches have been used to increase the purity and activity of bromelain enzyme preparations (Amid et al., 2011) and these strategies include ion exchange chromatography, ammonium sulphate fractionation, aqueous two-phase systems, as well as membrane filtration processes (Nor et al., 2015).

In downstream processing, it is difficult and expensive to selectively recover a targeted enzyme from a crude extract due to the low protein concentration among various contaminants and the similarity of their physical properties (Soares et al., 2012). In bromelain separation, for instance, there are other compounds such as phosphatases, glucosidases, peroxidases, cellulases, glycoproteins and carbohydrates (Silvestre et al., 2012) that may decrease the yield of purification.

Considering the increase of biotechnology, novel purification technologies are demanded to improve the overall enzyme yields and reduce the number of steps involved in the production of a specific one (Wu et al., 2017), as well as produce highly active biocatalysts (Amid et al., 2011). Thus, the study of both purification and alternative extraction methods is of great interest, aiming to obtain more economically feasible processes (Leite et al., 2012).

\section{Aqueous two-phase extraction (ATPE)}

Liquid-liquid extraction has awakened interest to be used as a step which replaces more expensive separation methods or decreases the number of stages required for the process (Ferreira et al., 2011). It has been widely used in bioseparation (Bala et al., 2012) since it provides an efficient method for fractionation of mixtures containing proteins, removing undesirable by-products such as polysaccharides, pigments and interfering proteins that decrease the activity of an enzyme (Babu et al., 2008).

ATPE is typically formed by mixing two hydrophilic polymers such as PEG (polyethylene glycol) and dextran or a polymer and a salt, such as PEG and potassium phosphate, in which phase separation occurs spontaneously apart from the critical concentrations of phase components (Silva et al., 2017; Ferreira et al., 2011). Under favorable conditions, the target protein tends to be partitioned into the top phase, which is less dense, less polar, for example, the PEG phase, while contaminant proteins are found in the denser, more polar and hydrophilic one, i.e., the dextran or salty phase, and can be removed through centrifugation (Arshad et al., 2014). These aqueous milieus are the convenient and suitable medium for the extraction of substances of biological origin, since the major constituent of the phases is water (70-90\%), which provides a pleasant medium for the work, with biologically active compounds, preserving their molecular stability and allowing, thus, their processing (Ferreira et al., 2011).

The distribution of enzyme molecules in ATPE is caused by two groups of factors. One of them comprehends those factors inherent to the system itself, including molecular weight and concentration of phase-forming polymers, type and concentration of salt, $\mathrm{pH}$, ionic strength and temperature. The other includes those factors which depend on the characteristics of the partitioned molecule: molecular weight, pI and surface properties. Separation of a target molecule from other components in a complex mixture is achieved by manipulating the partitioning behaviour by altering the average molecular weight of the polymers, the type of ions in the system, the ionic strength of the salt phase and the $\mathrm{pH}$. Therefore, the application of the technique requires hit-or-miss experimentation to design an adequate phase system for optimal partitioning of a protein (Rocha and Nerli, 2013; Arshad et al., 2014). 
Compared to other separation and purification methods, ATPE has many advantages such as low cost, ease of scale-up (Babu et al., 2008), scope for continuous operation (Nadzirah et al., 2013), volume reduction (Rabelo et al., 2004) and can be used in the early purification stages (Bala et al., 2012). Also, ATPE, featuring low interfacial tension, high biocompatibility and non-toxic, is attractive for recovery of enzymes from plants sources due to the low materials cost, minimal energy and time consumptions, and relatively high capacity that result in high yield ( $\mathrm{Wu}$ et al., 2017), making it an attractive alternative for isolation of biomolecules (Ketnawa et al., 2010).

Despite these favorable features, ATPE have not been extensively adopted in either industrial processes or commercial applications. The main reason for this could be attributed to the poor knowledge about the mechanisms involved in the partitioning equilibrium of macromolecules and, consequently, the lack of a comprehensive theory able to predict the experimental trends (Rocha and Nerli, 2013). Also, high concentrations of salts in wastewater are known to cause environmental problems (Silva et al., 2017).

Rabelo et al. (2004) studied the purification of bromelain using an ATPE system formed by thermoseparating copolymers: PEO (polyethylene oxide)-PPO (polypropylene oxide)- $\mathrm{PEO}$ (polyethylene oxide) and the best result (purification factor of 1.25) was achieved when using the conditions: copolymer with $10 \%$ EO $(\mathrm{m} / \mathrm{m})$ and molecular mass of $2000 \mathrm{~g} /$ mol, copolymer concentration of $5 \%(\mathrm{~m} / \mathrm{m})$ and temperature $5^{\circ} \mathrm{C}$ above the cloud point $\left(25^{\circ} \mathrm{C}\right.$ in this case), $\mathrm{pH} 6.0$ and salt concentration of $15 \mathrm{mM}$.

Babu et al. (2008) used 18\% PEG 1500 and 14\% potassium phosphate at $\mathrm{pH} 7$ for purification of bromelain and they obtained a purification factor of 4.0-fold. On the other hand, Ketnawa et al. (2010) purified bromelain from pineapple peel and reported a purification factor of 2.14-fold with 15\% PEG 2000 and $17 \% \mathrm{MgSO}_{4}$.

Ferreira et al. (2011) studied the application of the system PEG $400(16.23 \%)$ and potassium phosphate $(13.5 \%)$ at $\mathrm{pH} 7$ to purify bromelain from "curauá" (Ananas erectifolius LB Smith), a plant typical of northern and central-western Brazil, and they found a purification factor of 3.34. Rocha and Nerli (2013) evaluated the performance of PEG/sodium citrate in purifying bromelain at $\mathrm{pH}$ 5.20. They reported that PEG of higher molecular weights, particularly PEG 8000 , was the appropriate agent to recover most of the proteins in the salt-phase without affecting enzymatic activity. Wu et al. (2017) studied the purification of bromelain by a single step of polymer/salt aqueous biphasic system and reported that PEG 4000/phosphate with $17 \%(\mathrm{w} / \mathrm{w})$ of PEG 4000 and $14 \%(\mathrm{w} / \mathrm{w})$ of phosphate salt at $\mathrm{pH}$ of 8.0 showed a bromelain yield of $55.6 \%$ with a purification factor of 16.3 .

\section{Ion exchange chromatography (IEC)}

Chromatography involves separating the components of a mixture based on the rates at which they are carried through a stationary phase by a mobile phase, which may be liquid or gas (Novaes et al., 2016). Chromatographic techniques have been developed to separate bromelain from pineapple; including affinity membrane chromatography, capillary electrochromatography and ion exchange chromatography (Yin et al., 2011). The last one is an established technique used in the separation of charged molecules across a breadth of applications and industries (Levison, 2003).

Although the purification of therapeutic proteins, such as bromelain, is usually performed using at least an affinity chromatography step, it has been proposed that the level of purity required for pharmaceutical applications may also be obtained with non-affinity techniques such as ion exchange chromatography, which exhibits a large optimization margin compared to conventional processes (Salvalaglio et al., 2015).

The principle of ion exchange chromatography is that a charged analyte, in this case a protein, is bound to the stationary phase by means of electrostatic attraction (Nadzirah et al., 2013) and it happens because proteins have ionisable chemical portions which render them susceptible to charge enhancement or reversion as a function of $\mathrm{pH}$ (Levison, 2003).

There are basically two types of ion exchange chromatography: anion (AEC) and cation exchange chromatography (CEC). Anion, cation and mixed (anion and cation) columns are commonly used for protein purification, as proteins are complex ampholytes that have both positive and negative charges (Ramli et al., 2017). Positively charged molecules are separated using CEC columns, typically packed with $3-10 \mu \mathrm{m}$ particles and containing negatively charged acidic functional groups. These columns bind cationic species such as protonated bases through ionic interaction. In AEC mode, the stationary phase carries positively charged basic functional groups that are capable of binding anions (e.g., ionized carboxylic acids) (Fekete et al., 2015).

Although chromatography has been successfully used to separate bromelain from pineapple, it exhibits low separation efficiency and recovery and small sample loading capacity (Yin et al., 2011). Chromatographic steps and the products obtained by liquid chromatography are very expensive and have high added value due to the cost of the materials used in the production process (Costa et al., 2014). In addition, the separation performance is governed by various operating and column variables in a complicated manner; it is not easy to optimize the separation. The mobile phase properties such as $\mathrm{pH}$ and salt concentration very often affect the retention 
and the resolution of proteins significantly (Yamamoto and Ishihara, 1999).

The most often applied $\mathrm{pH}$ range for proteins in ion exchange chromatography separations is between 5.5 and 7.0. However, in some cases low $\mathrm{pH}$ around 3.5 is required to reach appropriate selectivity and retention (Fekete et al., 2015).

Devakate et al. (2009) obtained 3 times purer bromelain using ion exchange chromatography as compared to the ammonium sulfate precipitation method. The bromelain was found to be as much as 10fold purer with $84.5 \%$ enzyme recovery using cation exchange chromatography with an elution efficiency of $97.6 \%$

Gautam et al. (2010) studied the purification of bromelain-containing juice extracted from pineapple by a centrifugation technique at different rotational speed and DEAE (diethylaminoethyl) cellulose bedbased ion exchange chromatography. A GDU (gelatin digestion unit) was used to quantify the activity of the extract. They found that the process with ion exchange chromatography showed an activity of $14.87 \mathrm{GDU} / \mathrm{g}$, higher than the extract after centrifugation, equal to $3.50 \mathrm{GDU} / \mathrm{g}$.

Bresolin et al. (2013) purified bromelain from pineapple peel and they used ion exchange chromatography on DEAE- Sephafore as one of the steeps for separation in a way to increase the bromelain specific activity. The highest enrichment factor in terms of activity was achieved in the chromatography performed using potassium phosphate at $\mathrm{pH}$ 7.0. They reported that the eluted bromelain was recovered with just $2.3 \%$ of polysaccharide, which means an increase in specific activity. In fact, it increased from $0.52 \mathrm{U} /$ $\mathrm{mg}$ to $1.11 \mathrm{U} / \mathrm{mg}$.

Costa et al. (2014) employed two liquid chromatography steps: ion exchange chromatography (carboxymethylcellulose), followed by gel filtration chromatography for purification of bromelain and this method yielded a proteolytic value of $89 \%$ and purification factor of 16.93 .

\section{Precipitation}

Among the practical methods being applied for the large-scale recovery and purification of proteins from dilute solution, protein precipitation is considered as a key operational process, which is used during the early stages of the downstream processing (Silva et al., 2006). In this process, precipitation is usually induced by addition of a salt, an organic solvent, a non-ionic polymer, a metal, or by changing the $\mathrm{pH}$ to alter the nature of the solution (Novaes et al., 2016).

Organic solvents such as ethanol, ketones, methanol, propanol, and other alcohols have been widely employed in protein precipitation (Novaes et al., 2016). Among the salts, ammonium sulphate is the most commonly used to precipitate proteins in a partially purified form (Nadzirah et al., 2013). This is due to its high solubility, which allows for solutions of very high ionic strength, low price, and availability of pure material. Additionally, $\mathrm{NH}_{4}^{+}$and $\mathrm{SO}_{4}{ }^{2-}$ have been shown to stabilize protein structure (Duong-Ly and Gabelli, 2014).

The traditional methods for bromelain isolation by means of chemical precipitation usually comprise ammonium sulphate at $50 \%$, acetone $80 \%$ and ethanol $60 \%$. In these methods, the recovery of bromelain activity is around $85 \%$ with a purification factor 3-4.90 (Campos et al., 2017). However, when ethanol is used, there are some issues related to temperature increase when ethanol is added that require more complex control methods, and therefore makes this option unattractive (Coelho et al., 2014).

Precipitation methods have a lot of advantages such as low energy needed, efficiency to remove trace contaminants (Arshad et al., 2014), highly concentrated product, easy to apply at different scales, continuous operation viability at acceptable prices (Silvestre et al., 2012), simple equipment and many alternative precipitants, some of them inexpensive (Silva et al., 2006).

On the other hand, the main problem of these methods is the use of high concentrations of salt or solvents that in most cases cannot be discarded in the environment, so they must be recovered at the end of the process (Campos et al., 2017). It also implies that further purification steps are needed to separate proteins from the contaminants (Duong-Ly and Gabelli, 2014), such as dialysis (Arshad et al., 2014). In the case of ammonium sulphate, the recovery of this high soluble salt is difficult, so an increase in the cost of the total process is implicit (Campos et al., 2017).

An important property in the precipitation process is temperature. Low temperature is favorable to avoid denaturation during precipitation (Arshad et al., 2014). This is because, at low temperature, the flexibility of biomolecules is less, reducing the penetration capability of the solvent and minimizing the loss of activity (Soares et al., 2012).

Silva et al. (2006) recovered bromelain from triturated pineapple stem by a precipitation process with $99.5 \%$ alcohol at low temperature $\left(5^{\circ} \mathrm{C}\right)$ in a fed-batch stirred tank. They were concerned about designing a temperature controller for the experimental apparatus, so they did not discuss the yield of enzymatic activity.

Devakate et al. (2009) carried out the precipitation of bromelain by slow addition of ammonium sulfate at $4^{\circ} \mathrm{C}$, under constant stirring. They found that the fractions collected at $40-60 \%$ and $60-80 \%(\mathrm{w} / \mathrm{v})$ salt saturation had the highest specific protease activity and protein content as compared to other saturation levels. More specifically, it was observed that the 
$40-70 \%(\mathrm{w} / \mathrm{v})\left(\mathrm{NH}_{4}\right)_{2} \mathrm{SO}_{4}$ fraction contained $68 \%$ of the protease activity and an approximately 3 -fold increase in specific activity compared to the crude fruit juice, showing that about $80 \%$ of bromelain from the pineapple was recovered. Bresolin et al. (2013), using almost the same range of saturation, $40-80 \%$, recovered $75 \%$ of bromelain.

Soares et al. (2012) purified bromelain from pineapple wastes by ethanol precipitation using different concentrations of this alcohol $(20-90 \%)$ at $0^{\circ} \mathrm{C}$. Their results showed that bromelain was recovered in the range of 30 to $70 \%$, in which a purification factor of 2.28 -fold was achieved, keeping more than $98 \%$ of the total enzymatic activity.

Silvestre et al. (2012) used pineapple peel to obtain enzymatic extracts that were purified by three precipitation routes: one with ammonium sulphate, an isoelectric one and another with ethanol. They observed that the ethanolic route gave the highest specific activity (10.7 U/mg protein), at an optimum $\mathrm{pH}$ of 7.0 and $70^{\circ} \mathrm{C}$.

Chaurasya and Hebbar (2013) studied the separation of bromelain by ammonium sulphate and acetone precipitation. The results with ammonium sulphate showed that the activity recovery and purification increased as the concentration of the salt increased up to $50 \%$ saturation, when the protein content as well as activity recovery decreased. At the $50 \%$ of saturation level, higher values of protein and bromelain activity, recovery and purification $(28.13 \%, 86.26 \%$ and 3.07-fold, respectively) were obtained. For acetone purification, the maximum precipitation (5.56) was obtained at $60 \%$ concentration, but the activity recovery was low $(45.11 \%)$ compared to $85.97 \%$ obtained at $80 \%$ concentration with a purification of 4.9-fold.

Martins et al. (2014) purified bromelain from pineapple stem, bark and leaves by ethanol fractional precipitation at $4^{\circ} \mathrm{C}$. The results showed that bromelain was precipitated successfully in the $30-70 \%$ ethanol fraction, with a purification factor of 2.07 -fold and yielded over $98 \%$ of enzyme recovery. Campos et al. (2017) isolated bromelain by precipitation with carrageenan, which is a polysaccharide. With fixed concentration of bromelain $(3 \mathrm{mg} / \mathrm{mL})$ at $\mathrm{pH} 4.6$ and $25^{\circ} \mathrm{C}$, the minimum concentration of carrageenan necessary to precipitate bromelain was around $0.005 \%$ $\mathrm{w} / \mathrm{v}$, very low compared to other traditional protein precipitation methods. They noted that bromelain maintained its biological activity, with a yield of $80 \%$.

\section{Membranes}

Membrane technology and its equipment have become one of the most important techniques in industry. It has important economic and technical values and is therefore developing at high speed
(Zhang et al., 2010). Micro and ultrafiltration have been recently gaining popularity in the bioseparation industries (Bala et al., 2012). In terms of protein separation, membrane filtration is one of the most common methods used due to the good results. Thus, it has been extensively used both in laboratory and largescale processes (Novaes et al., 2016).

The membrane is a barrier that restricts totally or partially the transport of one or more chemical species present in the feed stream (Habert et al., 2006). In the case of ultrafiltration, the separation process is mainly based on molecular size differences (Bala et al., 2012) and the mass transfer rate during membrane filtration is governed by the pressure difference on both sides of the film (Novaes et al., 2016).

Bromelain can be purified from crude pineapple extract using membrane processes. In fact, membrane processes are considered the most attractive purification technology since they offers major advantages such as high throughput of product, scale up facilities due to the modular character, environmentally friendly, cost effective (Nor et al., 2016). Besides this, the processes are easy to operate, selective, can be applied in separation of thermolabile substances (Lima et al., 2009 ) and produce less waste during purification (Nor et al., 2015). A study of bromelain production cost by introducing membrane processes reported a substantial cost reduction, from 6.5 to 8.5 times, compared to liquid-liquid extraction (Nor et al., 2017a).

Recently, many studies have been conducted into the development of novel membrane materials, optimization of membrane fabrication procedures, and understanding membrane transport mechanisms (Shi et al., 2017).

\section{Ultrafiltration (UF)}

UF is an attractive method for separation and concentration of proteins and has been widely used on laboratory and commercial scales. Such membranes have molecular weight cut-offs ranging from 3 to 100 $\mathrm{kDa}$ (Ramli et al., 2017) and the permeate or retentate containing the protein of interest is further recycled until the desired concentration is achieved (Arshad et al., 2014).

Regarding bromelain purification, the required membrane pressure difference is between 0.5 to 4 bar, temperature range from 10 to $30^{\circ} \mathrm{C}, \mathrm{pH}$ may vary from 4 to 8.5 , with no corrosive compounds or chemicals involved (Nor et al., 2017a).

Some disadvantages of ultrafiltration are a long separation process and fouling (Arshad et al., 2014). Complex sugars such as polysaccharides in the pineapple extract affect membrane performance due to the agglomeration of these polymers with proteins under different physicochemical conditions, leading to severe fouling and significative flux decline (Nor 
et al., 2015). Aiming to minimize this problem, UF membranes are frequently operated in crossflow mode to improve the hydrodynamics by decreasing the mass boundary layer, which may decrease the time intervals to recover the flux (Saeki et al., 2017).

It has also been reported that additional steps of microfiltration, RME (reverse micellar extraction) and ATPS (aqueous two-phase system) before UF cause a significant increase in activity recovery (Arshad et al., 2014).

Doko et al. (1991) purified bromelain from pineapple juice using an integrated process formed by a membrane stage (including microfiltration in an $8 \mu \mathrm{m}$ mineral membrane and ultrafiltration in a polymeric film with molecular weight cut-off of 10 $\mathrm{kDa}$ ), followed by ammonium sulphate precipitation, ultracentrifugation and freeze drying. They reported a product with $98 \%$ of protein and increment of 2.8 fold in bromelain content, but the losses in bromelain content and in its enzymatic activity were attributed to the adsorption of the protein on the organic membrane.

Lopes et al. (2009) recovered bromelain extracted from juice pineapple using microfiltration (polyvinyl fluoride, pore diameter of $0.1 \mu \mathrm{m}$ ) followed by UF (Millipore kit, $10 \mathrm{kDa}, 4^{\circ} \mathrm{C}, 7000 \mathrm{rpm}, 20$ minutes). They previously filtered the juice through cotton and then studied the influence of $\mathrm{pH}$ (7.0 and 7.5) and membrane pressure difference $(0.05$ and 0.15 bar) on the activity recovery in a crossflow microfiltration process. They reported that $\mathrm{pH} 7.0$ or 7.5 , at 0.05 bar, were best for the activity recovery of bromelain enzyme (approximately 90\%). Moreover, UF produced a 10-fold concentrated bromelain extract.

Hebbar et al. (2012) studied the purification of bromelain from an aqueous extract of pineapple stem employing an integrated process of reverse micellar system and UF (membrane of cellulose acetate $5 \mathrm{kDa}$, 1 bar). They reported an activity recovery of $95.8 \%$ and purification of 8.9-fold.

Nor et al. (2015) studied the physicochemical and rheological properties of pineapple crude waste mixture, CWM, (57\% peel, 28\% crown and 15\% core) and related the results to membrane separation processes, aiming at the determination of the best operational conditions. The authors suggested the removal of pectin prior to UF due to the interaction of this polysaccharide with proteins and the polymeric membrane, as well as the increase in solution viscosity, which may increase the effects of fouling and, consequently, a flux decline of the process. They showed the Herschel-Bulkley rheological behaviour of different extracts and the effects of temperature and $\mathrm{pH}$ on the adjusted model. According to them, the membrane should have a molecular weight cut-off above $30 \mathrm{kDa}$ or below $10 \mathrm{kDa}$ for protein selectivity as permeate or as retentate, respectively, operating at $20-25^{\circ} \mathrm{C}$ and $\mathrm{pH} 7$.
In another paper, the same group employed a twostage ultrafiltration with ceramic membranes of 75 and $10 \mathrm{kDa}$ to perform bromelain separation from CWM in crossflow mode. They reported an enzyme recovery of $96.8 \%$ in the first UF stage, with $11.6 \mathrm{~kg} / \mathrm{m}^{2} \mathrm{~h}$, while the increment of enzyme specific activity was 2.5 -fold in the second stage, with permeate flux of $6.2 \mathrm{~kg} / \mathrm{m}^{2} \mathrm{~h}$. The highest flux was obtained when the $\mathrm{pH}$ of the feed was adjusted to 7 , near the membrane isoelectric point (Nor et al., 2016).

Recently, they varied the membrane pressure difference from 1 to 2 bar and the crossflow velocity, from 0.16 to $0.30 \mathrm{~m} / \mathrm{s}$ in the same twostage ultrafiltration ceramic membranes (75 and 10 $\mathrm{kDa}$, respectively). The fouling mechanisms were controlled by cake layer formation in stages 1 and 2, while the effect of pore blocking was also observed in the second membrane, probably due to the smaller pore diameter. The best bromelain recovery in stage 1 was $96.1 \%$, when the system operated at 2.0 bar and $0.30 \mathrm{~m} / \mathrm{s}$. On the other hand, the highest enzyme purity (1.7-fold) was observed when stage 2 was conducted at $1.0 \mathrm{bar}$ and $0.16 \mathrm{~m} / \mathrm{s}$ (Nor et al., 2017b).

Gil and Maupoey (2018) investigated pineapple valorisation by means of bromelain extraction and bioethanol production in an integrated process. Simultaneous saccharification and fermentation showed an increased bioethanol yield $(0.425$ $\left.\mathrm{g}_{\text {ethanol }} / \mathrm{g}_{\text {glucose }}\right)$ compared to direct fermentation and saccharification and fermentation of the solid waste $\left(0.375 \mathrm{~g}_{\text {ethanol }} / \mathrm{g}_{\text {glucose }}\right)$. Regarding bromelain extraction, the authors reported a 2-fold increase in enzyme concentration, with recovery of $53 \%$. Proteolytic activity of the freeze-dried product ranged from 340 to 805 GDU (gelatine digestion units).

\section{Affinity membranes (AM)}

Affinity membranes have been used to separate protein such as the ones from whey, beverages and egg (Zhang et al., 2010). The idea is that AM might combine the outstanding selectivity of affinity resins with the high productivity associated with filtration membranes (Klein, 2000).

Basically, the surface of a membrane is chemically modified with ligands to impart biospecific separation selectivity at the molecular level, based on specific interaction between the ligands and the target molecules through the adsorption process (Honjo et al., 2013). Adsorption can be defined as the binding of a dissolved solute to a solid adsorbent. The use of adsorption with a wide variety of adsorbents is becoming more common in bromelain preparations (Arshad et al., 2014). In fact, the integration of membrane and adsorption seems to be more suitable for bioseparation because of its high selectivity (Ogata et al., 2013).

The advantages of AM over traditional purification are better removal of macromolecules, microorganisms, 
and compounds that participate in fouling and improved quality of final product (Zhang et al., 2010), but the control of the degree and uniformity of modification is an issue to be pursued (Honjo et al., 2013).

The main reference about using an affinity membrane to separate bromelain is Zhang et al. (2010). They prepared a novel affinity membrane chemically modified with chitosan as a composite bilayer membrane, which in turn was covalently attached to Cibacron Blue, a stain specific to bromelain. It showed high bromelain adsorption capacity, $161.6 \mathrm{mg} / \mathrm{g}$, and concentration of 2.5-fold regarding the feed stream. The experimental equilibrium data fitted the Freundlich isotherm. They also reported that the membrane was recovered and utilized for three times without losing its adsorption capacity.

\section{PROCESS COMPARISON}

Table 1 summarizes the advantages and limitations of each process, as well as some remarkable results. It is worth noting that the direct comparison of the published data is a difficult task due to the variety of bromelain sources and test conditions. In addition to it, the responses are not on the same basis, which may lead to huge discrepancies. However, it seems that the purification factor and activity recovery are quite usual and they are reported here as the main results of the literature.

ATPE showed the highest purification factor, although the activity of bromelain showed a remarkable decrease. One of the main disadvantages of this process is the high salt concentration, which is hard to recover aiming at reuse. This also leads to low purity of the product.

Precipitation also presents the same inconvenience of high precipitant content, which makes it unattractive regarding the environment. However, the good results together with low cost makes this process one of the most used nowadays, especially for commercial applications.

IEC is the most expensive technique due to the low separation efficiency, low recovery and small sample loading capacity. The higher purification obtained by combining IEC and gel filtration chromatography reported by Costa et al. (2014) should also be noted. This is an indication that the combination of process may lead to better results, which can be an interesting solution for the problem.

UF membranes seem to be a promising alternative to large-scale operation, since the fouling is controlled by means of crossflow modes, together with good pretreatment processes and periodic backflush. AM are still incipient and deserve more studies to be compared to the former processes.

As a matter of fact, the most common tendency is the combination of processes, such as microfiltration prior of ultrafiltration (Nor et al., 2017b), integration of reverse micellar systems with UF (Hebbar et al., 2012) and the use of pineapple extract as the source of other biochemicals in the process to make it economically viable (Gil and Maupoey, 2018).

\section{CONCLUSION}

Bromelain is of high interest in many fields and its recovery from wastes is potentially economical. The main separation and concentration techniques were presented in this review aiming at a comparison of the pros and cons of each one of them: precipitation, aqueous two-phase extraction, ion exchange chromatography and membrane filtration. Although the literature shows different aspects of the separation, such as enzymatic activity, bromelain concentration or purification of the

Table 1. Comparison between the separation methods: advantages, limitations and remarkable results reported.

\begin{tabular}{|c|c|c|c|c|c|}
\hline $\begin{array}{c}\text { Separation } \\
\text { method }\end{array}$ & Advantages & Limitations & $\begin{array}{c}\text { Purification fold } \\
(-)\end{array}$ & $\begin{array}{c}\text { Activity recovery } \\
(\%)\end{array}$ & Reference \\
\hline ATPE & $\begin{array}{l}\text {-Aqueous milieu; } \\
\text {-Low cost. }\end{array}$ & $\begin{array}{l}\text { - Poor knowledge } \\
\text { of mechanisms; } \\
\text { - High salt content. }\end{array}$ & 16.3 & 55.6 & Wu et al. (2017) \\
\hline IEC & $\begin{array}{l}\text { - Mild operation } \\
\text { condition. }\end{array}$ & $\begin{array}{l}\text { - High cost; } \\
\text { - Hard to optimize } \\
\text { due complexity. }\end{array}$ & 10 & 84.5 & $\begin{array}{c}\text { Devakate et al. } \\
\text { (2009) }\end{array}$ \\
\hline Precipitation & $\begin{array}{l}\text { - Low energy } \\
\text { needed; } \\
\text { - Many alternative } \\
\text { precipitants. } \\
\text { - High throughput }\end{array}$ & $\begin{array}{l}\text { - High precipitant } \\
\text { (salt) content; } \\
\text { - Hard to recover } \\
\text { the precipitant. }\end{array}$ & 4.9 & 85.97 & $\begin{array}{l}\text { Chaurasya and } \\
\text { Hebbar (2013) }\end{array}$ \\
\hline UF & $\begin{array}{c}\text { of product; } \\
\text { - Environmentally } \\
\text { friendly; } \\
\text { - Scale up facilities. }\end{array}$ & $\begin{array}{l}\text { - Membrane } \\
\text { fouling. }\end{array}$ & 10 & 90 & Lopes et al. (2009) \\
\hline $\mathrm{AM}$ & - Higher selectivity. & $\begin{array}{l}\text { - Hard to control } \\
\text { uniformity of } \\
\text { modification. }\end{array}$ & 2.5 & - & Zhang et al. (2010) \\
\hline
\end{tabular}


product, it was possible to infer that the choice of a route should be done depending on the final application.

Ion exchange chromatography is one of the most expensive methods, due to the small sample loading capacity combined with the high cost of materials used in this process. Precipitation and aqueous twophase extraction have the disadvantage of dealing with high salt concentration streams, which are difficult to discharge and recover. Membranes have been investigated to surpass the limitation of fouling by means of studying the effects of polysaccharides and other macromolecules on the flux decrease. The search for the effect of the conditions on the final product quality is of utmost importance and the use of hybrid processes may be a technical and economic solution.

\section{ACKNOWLEDGMENTS}

Authors thank Capes, CNPq and Fapemig for the financial support.

\section{REFERENCES}

Amid, A., Ismail, N.A., Yusof, F., Salleh, H.M. Expression, purification, and characterization of a recombinant stem bromelain. Process Biochem., 46, 2232-2239 (2011). https://doi.org/10.1016/j. procbio.2011.08.018

Arshad, Z.I.M., Amid, A., Yusof, F., Jaswir, I., Ahmad, K., Loke, S.P. Bromelain: an overview of industrial application and purification strategies. Appl. Microbiol Biotechnol., 98, 7283-7297 (2014). https://doi.org/10.1007/s00253-014-5889-y

Arumugam, A., Ponnusami, V. Pineapple fruit bromelain recovery using recyclable functionalized ordered mesoporous silica synthesized from sugarcane leaf ash. Braz. J. Chem. Eng., 30, 477-486 (2013). https://doi.org/10.1590/S010466322013000300006

Babu, B.R., Rastogi, N.K., Raghavarao, K.S.M.S. Liquid-liquid extraction of bromelain and polyphenol oxidase using aqueous two-phase system. Chem. Eng. Process., 47, 83-89 (2008). https://doi.org/10.1016/j.cep.2007.08.006

Bala, M., Ismail, N.A., Mel, M., Jami, M.S., Mohd Salleh, H., Amid, A. Bromelain production: Current trends and perspective. Archives des Sciences, 65, 369-399 (2012).

Bala, M., Ismail, N.A., Mel, M., Jami, M.S., Mohd Salleh, H., Amid, A. Kinetic studies on recombinant stem bromelain. Adv. Enzyme Res., 1, 52-60 (2013). https://doi.org/10.4236/aer.2013.13006

Bernela, M., Ahuja, M., Thakur, R. Enhancement of anti-inflammatory activity of bromelain by its encapsulation in katira gum nanoparticles. Carbohydr. Polym., 143, 18-24 (2016). https://doi. org/10.1016/j.carbpol.2016.01.055
Bresolin, I.R.A.P., Bresolin, I.T.L., Silveira, E., Tambourgi, E.B., Mazzola, P.G. Isolation and Purification of Bromelain from Waste Peel of Pineapple for Therapeutic Application. Braz. Arch. Biol. Technol., 56, 971-979 (2013). https://doi. org/10.1590/S1516-89132013000600012

Campos, D.A., Valetti, N.W., Oliveira, A., PastranaCastro, L.M., Teixeira, J.A., Pintado, M.M., Picó, G. Platform design for extraction and isolation of Bromelain: Complex formation and precipitation with carrageenan. Process Biochem., 54, 156-161 (2017). https://doi.org/10.1016/j. procbio.2016.12.014

Chaurasiya, R.S., Hebbar, H.U. Extraction of bromelain from pineapple core and purification by RME and precipitation methods. Sep. Purif. Technol., 111, 90-97 (2013). https://doi.org/10.1016/j. seppur.2013.03.029

Coelho, D.F., Silveira, E., Tambourgi, E.B. Purification Processes and Market Potential of Bromelain in Brazil. J. Chem. Chem. Eng., 8, 882-888 (2014). https://doi.org/10.17265/1934-7375/2014.09.007

Corso, C.A, Waliszewski, K.N., Welti-Chanes, J. Pineapple fruit bromelain affinity to different protein substrates. Food Chem., 133, 631-635 (2012). https://doi.org/10.1016/j.foodchem.2011.05.119

Costa, H.B., Fernandes, P.M.B., Romão, W., Ventura, J.A. A new procedure based on column chromatography to purify bromelain by ion exchange plus gel filtration chromatographies. Ind. Crops Prod., 59, 163-168 (2014). https://doi. org/10.1016/j.indcrop.2014.04.042

Devakate, R.V., Patil, V.V., Waje, S.S., Thorat, B.N. Purification and drying of bromelain. Sep. Purif. Technol., 64, 259-264 (2009). https://doi. org/10.1016/j.seppur.2008.09.012

Doko, M.B., Bassani, V., Casadebaig, J., Cavailles, L., Jacob, M. Preparation of proteolytic enzyme extracts from Ananas comosus L., Merr.fruit juice using semipermeable membrane, ammonium sulphate extraction, centrifugation and freezedrying processes. Int. J. Pharm., 76, 199-206 (1991). https://doi.org/10.1016/0378-5173(91)90272-P

Dossa, D., Fuchs, F. (2018, April 25). Abacaxi: produção, mercado e preços na CEASA-PR [Technical report 2017]. Retrieved from http:// www.ceasa.pr.gov.br/arquivos/File/BOLETIM/ Informe_Tecnico_Abacaxi.pdf

Duong-Ly, K., Gabelli, S.B. Salting out of proteins using ammonium sulfate precipitation. Methods in Enzymol., 541, 85-94 (2014). https://doi. org/10.1016/B978-0-12-420119-4.00007-0

Fekete, S., Beck, A., Veuthey, J., Guillarme, D. Ionexchange chromatography for the characterization of biopharmaceuticals. J. Pharm. Biomed. Anal., 113, 43-55 (2015). https://doi.org/10.1016/j. jpba.2015.02.037 
Ferreira, J.F., Sbruzzi, D., Barros, K.V.G., Machado, I.S., Tambourgi, E.B. Purificação da enzima bromelina presente no curauá (Ananas erectifolius L.B. SMITH) variedade roxa, por sistema bifásico aquoso PEG 4000/fosfato de potássio. Rev. Bras. Prod. Agroind., 13, 197-202 (2011). https://doi. org/10.15871/1517-8595/rbpa.v13n2p197-202

Gautam, S.S., Mishra, S.K., Dash, V., Goyal, A.K., Rath, G. Comparative study of extraction, purification and estimation of bromelain from stem and fruit of pineapple plant. Thai J. Pharm. Sci., 34, 67-76 (2010).

Gil, L.S., Maupoey, P.F. An integrated approach for pineapple waste valorisation. Bioethanol production and bromelain extraction from pineapple residues. J. Cleaner Prod., 172, 1224-1231 (2018). https:// doi.org/10.1016/j.jclepro.2017.10.284

Habert, A. C., Borges, C. P., Nobrega, R. Processos de separação com membranas. Rio de Janeiro, E-papers, (2006).

Hale, L.P., Greer, P.K., Trinh, C.T., James, C.L. Proteinase activity and stability of natural bromelain preparations. Int. Immunipharmacol., 5, 783-793 (2005). https://doi.org/10.1016/j. intimp.2004.12.007

Hebbar, U.H., Sumana, B., Hemavathi, A.B. Separation and Purification of Bromelain by Reverse Micellar Extraction Coupled Ultrafiltration and Comparative Studies with Other Methods. Food Bioprocess Technol., 5, 1010-1018 (2012). https:// doi.org/10.1007/s11947-010-0395-4

Honjo, T., Hoe, K., Tabayashi, S., Tanaka, T., Shimada, J., Goto, M., Matsuyama, H., Maruyama, T. Preparation of affinity membranes using thermally induced phase separation for one-step purification of recombinant proteins. Anal. Biochem., 434, 269-274 (2013). https://doi.org/10.1016/j. ab.2012.11.027

Ketnawa, S., Chaiwut, P., Rawdkuen, S. Pineapple wastes: a potential source for bromelain extraction. Food Bioprod. Process., 90, 385-391 (2012). https://doi.org/10.1016/j.fbp.2011.12.006

Ketnawa, S., Rawdkuen, S., Chaiwut, P. Two phase partitioning and collagen hydrolysis of bromelain from pineapple peel Nang Lae cultivar. Biochem. Eng., 52, 205-211,(2010). https://doi.org/10.1016/j. bej.2010.08.012

Klein, E. Affinity membranes: a 10-year review. J. Membr. Sci., 179, 1-27 (2000). https://doi. org/10.1016/S0376-7388(00)00514-7

Leite, N.S, Lima, A.A.B., Santana, J.C.C., Lopes, F.L.G., Lédo, A.S., Tambourgi, E.B., Souza, R.R. Determination of Optimal Condition to Obtain the Bromelain from Pineapple Plants Produced by Micropropagation. Braz. Arch. Biol. Technol., 55, 647-652 (2012). https://doi.org/10.1590/S151689132012000500002
Levison, P.R. Large-scale ion-exchange column chromatography of proteins. Comparison of different formats. J. Chromatogr. B, 790, 17-33 (2003). https:// doi.org/10.1016/S1570-0232(03)00087-4

Lima, G.A., Santana, M.F., Souza, R.R. Otimização do processo de recuperação e concentração da bromelina utilizando membranas cerâmicas. Scientia Plena, 5, 1-5 (2009).

Lopes, F.L.G., Severo Júnior, J.B., Souza, R.R.D., Ehrhardt, D.D., Santana, J.C.C., Tambourgi, E.B. Concentration by membrane separation processes of a medicinal product obtained from pineapple pulp. Braz. Arch. Biol. Technol., 52, $457-464$ (2009). https://doi.org/10.1590/S1516-89132009000200024

Martins, B.C., Rescolino, R., Coelho, D.F., Zancheta, B., Tambourgi, E.B., Silveira, E. Characterization of bromelain from Ananas Comosus agroindustrial residues purified by ethanol factional precipitation. Chem. Eng. Trans., 37, 781-786 (2014). https://doi. org/0.3303/CET1437131

Murachi, T., Takahashi, N. Microbial Proteases. In Desnuelle, P., Neurath, H., Ottesen, M. StructureFunction Relationships of Proteolytic Enzyme. New York, Academic Press, 85-96 (1969).

Nadzirah, K.Z., Zainal, S., Noriham, A., Normah, I. Efficacy of selected purification techniques for bromelain. Int. Food Res. J., 20, 43-46 (2013).

Nor, M.Z.M., Ramchandran, L., Duke, M., Vasiljevic, T. Characteristic properties of crude pineapple waste extract for bromelain purification by membrane processing. Food Bioprod. Process., 52, 7103-7112 (2015). https://doi.org/10.1007/s13197-015-1812-5

Nor, M.Z.M., Ramchandran, L., Duke, M., Vasiljevic, T. Separation of bromelain from crude pineapple waste mixture by a two-stage ceramic ultrafiltration process. Food Bioprod. Process., 98, 142-150 (2016). https://doi.org/10.1016/j.fbp.2016.01.001

Nor, M.Z.M., Ramchandran, L., Duke, M., Vasiljevic, T. Application of membrane-based technology for purification of bromelain. Int. Food Res. J., 24, 1685-1696 (2017a).

Nor, M.Z.M., Ramchandran, L., Duke, M., Vasiljevic, $\mathrm{T}$. Integrated ultrafiltration process for the recovery of bromelain from pineapple waste mixture. J. Food Process Eng., 40, e12492 (2017b). https://doi. org/10.1111/jfpe. 12492

Novaes, L.C.L., Jozala, A.F., Lopes, A.M., SantosEbinuma, V.C., Mazzola, Pessoa Junior, A. Stability, Purification, and Applications of Bromelain: A Review. Biotechnol. Prog., 32, 5-13 (2016). https:// doi.org/10.1002/btpr.2190

Ogata, Y., Seto, H., Murakami, T., Hoshino, Y., Miura, Y. Affinity Separation of Lectins Using Porous Membranes Immobilized with Glycopolymer Brushes Containing Mannose or N-Acetyl-DGlucosamine. Membranes, 3, 169-181 (2013). https://doi.org/10.3390/membranes3030169 
Pavan, R., Jain, S., Shraddha, Kumar, A. Properties and Therapeutic Application of Bromelain: A Review. Biotechnol. Res. Int., 2012, 1-6 (2012). https://doi. org/10.1155/2012/976203

Rabelo, A.P.B., Tambourgi, E.B., Pessoa Jr., A. Bromelain partitioning in two-phase aqueous systems containing PEO-PPO-PEO block copolymers. J. Chromatogr. B, 807, 61-68 (2004). https://doi.org/10.1016/j.jchromb.2004.03.029

Ramli, A.N.M., Aznan, T.N.T., Illias, R.M. Bromelain: from production to commercialization. J. Sci. Food. Agri., 97, 1386-1395 (2017). https://doi. org/10.1002/jsfa.8122

Rocha, M.V., Nerli, B.B. Molecular features determining different partitioning patterns of papain and bromelain in aqueous two-phase systems. Int. J. Biol. Macromol., 61, 204-211 (2013). https://doi. org/10.1016/j.ijbiomac.2013.06.055

Saeki, D., Minami, R., Matsuyama, H. Effects of operating conditions on biofouling in crossflow ultrafiltration membrane processes. Sep. Purif. Technol., 189, 138-144 (2017). https://doi. org/10.1016/j.seppur.2017.07.079

Salvalaglio, M., Paloni, M., Guelat, B., Mobidelli, M., Cavallotti, C. A two level hierarchical model of protein retention in ion exchange choromatography. J. Chromatogr. A, 1411, 50-62 (2015). https://doi. org/10.1016/j.chroma.2015.07.101

Shi, B., Marchetti, P., Peshev, D., Zhang, S., Livingston, A.G. Will ultra-high permeance membranes lead to ultra-efficient process? Challenges for molecular separations in liquid systems. J. Memb. Sci., 525, 35-47 (2017). https://doi.org/10.1016/j. memsci.2016.10.014

Silva, F.V., Santos, R.L.A., Fileti, A.M.F. Adaptive control of bromelain precipitation in a fedbatch stirred tank [International Symposium on Advanced Control of Chemical Processes in Gramado, Brazil (2006). Retrieved from https:// ac.els-cdn.com/S1474667016354556/1-s2.0S1474667016354556-main.pdf?_tid=6c0b5c82f15d-4d87-9e8c-32b32691 aae7\&acdnat $=1524702$ 268 7ebcf7c8331e5dba8cee07708515e408

Silva, O.S., Gomes, M.H.G., Oliveira, R.L., Porto, A.L.F., Converti, A., Porto, T.S. Partitioning and extraction protease from Aspergillus tamari URM4634 using PEG-citrate aqueous twophase systems. Biocatalysis and Agricultural Biotechnology, 9, 168-173 (2017). https://doi. org/10.1016/j.bcab.2016.12.012
Silvestre, M.P.C., Carreira, R.L., Silva, M.R., Corgosinho, F.C., Monteiro, M.R.P., Morais, H.A. Effect of $\mathrm{pH}$ and temperature on the activity of enzymatic extracts from pineapple peel. Food Bioprocess Tech., 5, 1824-1831 (2012). https://doi. org/10.1007/s11947-011-0616-5

Soares, P.A.G, Vaz, A.F.M., Correia, M.T.S., Pessoa Jr, A., Carneiro-da-Cunha, M.G. Purification of bromelain from pineapple wastes by ethanol precipitation. Sep.Purif. Technol., 98, 389-395 (2012). https://doi.org/10.1016/j. seppur.2012.06.042

Souza, G.R., Silva, A.A., Carreira, R.L., Silvestre, M.P.C. Obtenção de bromelina e caracterização da atividade proteolítica visando a sua utilização na produção de suplemento dietético para fenilcetonúricos (2005). Retrieved from http:// zymelift.com.br/site/artigos/12.pdf.

Tap, F.M., Majid, F.A.A., Khairudin, N.B.A. Structure prediction of Stem Bromelain from pineapples (Ananas Comosus) using procaricain enzyme as a modelling template. Int. J. App. Eng. Res., 9, 61096111 (2016).

Wan, J., Guo, J., Miao, Z., Guo, X. Reverse micellar extraction of bromelain from pineapple peelEffect of surfactant structure. Food Chem., 197, 450-456 (2016). https://doi.org/10.1016/j. foodchem.2015.10.145

Wu, W., Ng, H.S., Sun, I., Lan, J.C. Single step purification of bromelain from Ananas comosus pulp using a polymer/salt aqueous biphasic system. J. Taiwan Inst. Chem. Eng., 79, 158-162 (2017). https://doi.org/10.1016/j.jtice.2017.04.001

Yamamoto, S., Ishihara, T. Ion-exchange chromatography of proteins near the isoelectric points. J. Chromatogr. A., 852, 31-36 (1999). https://doi.org/10.1016/S0021-9673(99)00593-2

Yin, L., Sun, C.K., Han, X., Xu, L., Xu, Y., Qi, Y., Peng, J. Preparative purification of bromelain (EC 3.4.22.33) from pineapple fruit by highspeed counter-current chromatography using a reverse-micelle solvent system. Food Chem., 129, 925-932 (2011). https://doi.org/10.1016/j. foodchem.2011.05.048

Zhang, H., Nie, H., Yu, D., Wu, C., Zhang, Y., White, C.J.B., Zhu, L. Surface modification of electrospun polyacrylonitrile nanofiber towards developing an affinity membrane for bromelain adsorption. Desalination, 256, 141-147 (2010). https://doi. org $/ 10.1016 /$ j.desal.2010.01.026 
